\title{
METHODOLOGICAL SUPPORT OF PROFESSIONAL DEVELOPMENT OF TEACHERS OF PRESCHOOL EDUCATION INSTITUTIONS: PSYCHOLOGICAL AND PEDAGOGICAL FOUNDATIONS
}

\author{
Olena Kovalenko \\ Candidate of Pedagogical Sciences, Associate Professor, \\ Associate Professor at the Department of Preschool Education, Pedagogical, \\ Institute of Borys Hrynchenko Kyiv University, Ukraine \\ e-mail: kovalenko@kubg.edu.ua, orcid.org/0000-0002-5957-7256
}

\section{Diana Lakhman}

Student, Pedagogical Institute of Borys Hrynchenko Kyiv University, Ukraine e-mail: dolakhman.pi20@kubg.edu.ua, orcid.org/0000-0001-7160-159X

\section{Summary}

With the help of encyclopedias, dictionaries, reference books the article reveals the definitive characteristics of such basic research concepts as: methodological assistance, methodological work and methodological support. Based on the development of psychological and pedagogical research, the concepts of methodological work and methodological support are analyzed and differentiated. The domestic regulatory documents are cited, which reflect the issues of methodological support for the teachers. The elaborations of the main directions and forms of methodical work with teachers (mass, group and individual) are presented, the classification of principles and functions of methodical support is given. The list of interactive forms of methodological support for preschool teachers and their impact on improving methodological support for teachers is outlined. The concept of the professional development of teachers, components of professional development, their essence and structure are highlighted, as well as ways of influence of the methodological support on its improvement are outlined.

The article, based on reputable modern researchers and practitioners, defines the directions, features and psychological and pedagogical conditions for providing methodological support for the professional development of teachers of preschool education institutions. The problems of implementing methodological support for teachers in preschool institutions are listed and analyzed, as well as prospects for improving its effectiveness are outlined.

Keywords: professional development of teachers, components of professional development, pedagogical competence, methodological support, diagnostics of teachers.

\section{DOI: https://doi.org/10.23856/4606}

\section{Introduction}

Constant updating of the content and technologies of education makes it necessary to systematically update the forms of organization, methods and content of methodological work. The current stage of development of preschool education is characterized by the search for new approaches in pedagogical theory and practice. One of the important issues of education reform defined in the State national program «Education» («Ukraine XXI century») is «updating the content, forms and methods of preschool education, in accordance with the age characteristics of preschool children» (State national program «Education» («Ukraine XXI century»), 1993). 
An important factor in improving the quality of education is the high level of competence of the teacher, which, in turn, depends on the effectiveness of the methodological support system. New requirements for the personality of a preschool teacher and the range of his functional responsibilities justify the need to study the problem of his professional development, ways and methods of optimizing this process. One of the mandatory conditions and effective ways to optimize the process of acquiring the proper level of professionalism by preschool teachers, as well as the success of their adaptation in the system of professional work, is to provide directions for methodological support for their professional development.

\section{Formulation of the purpose of the article}

The purpose of the article is to study the aspects of implementing methodological support for the process of professional development of teachers of preschool education institutions.

\section{Presentation of the main material of the article}

Our task at the first stage of the research was to work out the definitive characteristics of the main concepts of the study: «methodological work» and «methodological support». For this purpose, we have used encyclopedias, explanatory and spelling dictionaries, reference books, and so on.

In the Academic explanatory dictionary of the Ukrainian language, the concept of «support» is defined in several contexts: as an action with an indication to support; as something that support an action, phenomenon; as a group of people supporting someone; as an addition of something. Thus, the genesis of the concept of «support» is the joint actions of people based on mutual assistance to each other in a common cause. Related words to the concept of «support» are: «cooperation», «interaction», «mutual assistance» (Academic explanatory dictionary of the Ukrainian language, 1979).

Dialectical analysis of the term «methodical work» comes from «methodical» and is mainly interpreted in two meanings: 1) consistent, systematic, acting according to the plan; 2) one who acts according to the rules of the methodology, is connected or belongs to it (Nochvolod, 2008: 126).

In the Comprehensive Dictionary, the concept of «methodical» is interpreted as «a set of interrelated ways and techniques of expedient conduct of any work; teaching about methods of teaching a certain science, subject» (Busel et al., 2005: 522).

In the dictionary of basic concepts from the course «Pedagogy» we find the following definition of methodological work: a form of organization of purposeful activity of a teacher to improve their professional level. Methodological work contributes to the mutual enrichment of members of the teaching staff with pedagogical findings, provides an opportunity for young teachers to learn pedagogical skills from older and more experienced colleagues, ensures the maintenance of the spirit of creativity in the teaching staff, the desire for search (Antonova et al., 2014: 49).

The dictionary-reference book on pedagogy defines methodological work as a special structural and organizational form in an educational institution; part of the continuing education of teachers, educators (Myzherykov, 2004: 203).

In the Encyclopedia of Education, methodological work is defined as integral, based on the achievements of science, educational innovations, a specific analysis of the state of the educational process, a system of diagnostic, search, analytical, informational, organizational 
activities and measures aimed at comprehensive improvement of the professional skills of each teacher, the development of the creative potential of the teaching staff as a whole and improving the quality of educational work (Kremen et al., 2008: 497).

The need to modernize the methodological work of teachers led to the introduction into pedagogical practice such concepts as «support», «scientific and methodological support», «co - creation» (Muromets, 2008: 321).

According to the Comprehensive Dictionary, the word «support» means an action meaning «to accompany, to accompany»: «To go, with someone as a companion; to seeing someone off to a certain place. Go, go guarding» or «showing the way to someone», "watch who or what is moving away, add something to something» (Busel et al., 2005, 1415).

Similar concepts to» support «are - «cooperation», «assistance» (Maksymenko, 2013: 7). In addition, semantic analysis of this concept allows us to draw conclusions about the presence in the content of this concept of three components: subjects-fellow travelers, the person accompanying them and the path that they pass together (Mishchenko, 2016: 239).

Thus, based on the development of a number of reference sources, we drew the following conclusions: the concept of «support» provides training, pedagogical assistance and maintenance, provides not a solution to the problem for the teacher, but the organization and stimulation of his amateur activities and creating conditions for solving his own problems. At the same time, it emphasizes the non-interference of one subject in the activities of another until they feel the need for interaction.

At the second stage, the content of our work was the development of domestic regulatory documents on methodological support. Our analysis of the documents showed that this issue is reflected in such documents as: the Laws of Ukraine «On education» and «On preschool education», the Approximate regulations on the methodological office of a preschool education institution», etc. Thus, Article 54 of the Law of Ukraine «On education» states that teachers are obliged to «constantly improve their professional and general cultural levels and pedagogical skills; perform an educational program to achieve the learning results provided for by education applicants; promote the development of abilities of education applicants» (Of the Law of Ukraine «On Education», 2017).

The Law of Ukraine «On preschool education» defines the tasks of scientific and methodological support for the preschool education system, in particular: training, retraining and advanced training of teachers of the preschool education system (Law of Ukraine «On Preschool Education», 2001).

In «The approximate regulations on the methodological office of a preschool education institution», the issues of methodological support are presented more specifically and in detail. In particular, it is indicated here that the center of assistance for the teachers of preschool education institutions on ensuring the holistic development of the child, his physical, intellectual and creative abilities through education, training, socialization and the formation of necessary life skills is a methodological office. Among the main tasks of the methodological office we see: creating a reflexive and innovative environment in preschool institutions; identifying promising pedagogical experience in the staff of preschool education institutions and beyond; providing practical assistance to young specialists; ensuring the implementation of advanced training of teachers; forming and/or replenishing, updating the information data bank (catalogs or card files on electronic or/and paper) on the content of preschool education; promoting the participation of the staff of preschool education in innovative educational activities; informing teachers about regulatory documents in the field of preschool education, various types of educational literature on preschool education and periodicals professional publications, providing practical 
assistance in their use, etc. (The approximate regulations on the methodological office of a preschool education institution, 2018).

Processing the results of research by psychologists and teachers on the issue of methodological support was the content of our work at the third stage. A deep analysis of scientific research has given us the opportunity to identify certain areas of research, namely: 1) the content and organization of methodological support in the context of methodological work in educational institutions of various levels (I. Bekh, N. Vasylenko, M. Voitsekhivskyi, N. Dudnichenko, I. Zhernosek, A. Zaichenko, A. Kocherga, S. Muromets, S. Makarenko, I. Romanyuk, L. Sysoeva, T. Sorochan, T. Sushchenko, etc.); 2) the study of the issues of the organization of methodological support of educational activities and practical experience in preschool institutions (G. Belenka, A. Bogush, K. Volynets, N. Gavrysh, A. Goncharenko, N. Dyatlenko, O. Kovalenko, L. Kozak, O. Kornieieva, O. Kocherga, K. Krutii, M. Mashovets, L. Melenets, T. Pirozhenko, O. Polovina, T. Ponomarenko, I. Romanyuk, G. Smolnikova, I. Tereshchenko, etc.).

In most studies, methodological work is considered as one of the components of the system of advanced training of teachers. Thus, in the dissertation research of O. Korneeva, based on the research of I. Bekh, G. Bielienkaya, A. Bogush, N. Gavrysh, A. Goncharenko, N. Dudnichenko, I. Zhernosek, I. Romanyuk and others, determines that the organization of methodological work with preschool teachers is a purposeful work of a teacher-methodologist with teachers in order to increase their pedagogical skills and evaluative-reflexive activity of methodological orientation. The content of the methodological work is the teacher's awareness of the needs of society in the form of a social order regarding the results of his professional activity and their implementation, which is carried out on the basis of advanced pedagogical experience (Korneeva, 2012).

According to I. Romanyuk, methodological work in preschool institutions is an integral part of the unified system of continuing education of teachers, a system for improving their professional skills. The author considers that the main task of methodological work is to provide real assistance to teachers «in the development of their skills as a complex of professional knowledge, skills necessary in working with children and their parents» (Romanyuk, 2019: 56).

K. Krutii notes: «methodological work in a modern preschool educational institution should be as flexible as possible, namely, to promote the development of creativity, initiative, and improve the quality of the educational process. The solution of these problems lies in the search for new content, forms and methods of working with the pedagogical team» (Krutii, 2004: 4).

I. Zhernosek defines methodological work as a specially organized activity of the teaching staff, which creates comfortable conditions (environment) for improving the teacher's skills. The more fully teachers use the opportunities of the environment, the more successful is their free and active self-development and the level of educational activity of the educational institution, «its functions are to determine the system of measures aimed at achieving the best results» (Zhernosek, 2001: 5).

It is worth noting that until recently, the functions of methodological work were mainly limited to directing and monitoring the activities of educators. However, the reform of the entire education system, which is relevant in time, including the modernization of preschool education, requires updating the methodological work.

N. Dyatlenko notes that» on the threshold of the third millennium, the Ukrainian educational system has reached transformational limits, the multi-vector nature of which is striking in its diversity and unpredictability. «The scientist points out the need for specialists who «in modern fleeting changes in the education system have the ability to work with others for 
the predicted result, prevent and resolve conflicts, reach compromises, respect human rights, observe the socio-cultural diversity of history» (Dyatlenko, 2009: 58).

Based on the research materials (I. Zhernosek, O. Kornieieva, K. Krutii, etc.), we will determine the main directions of methodological work in a general form (Scheme 1.1):

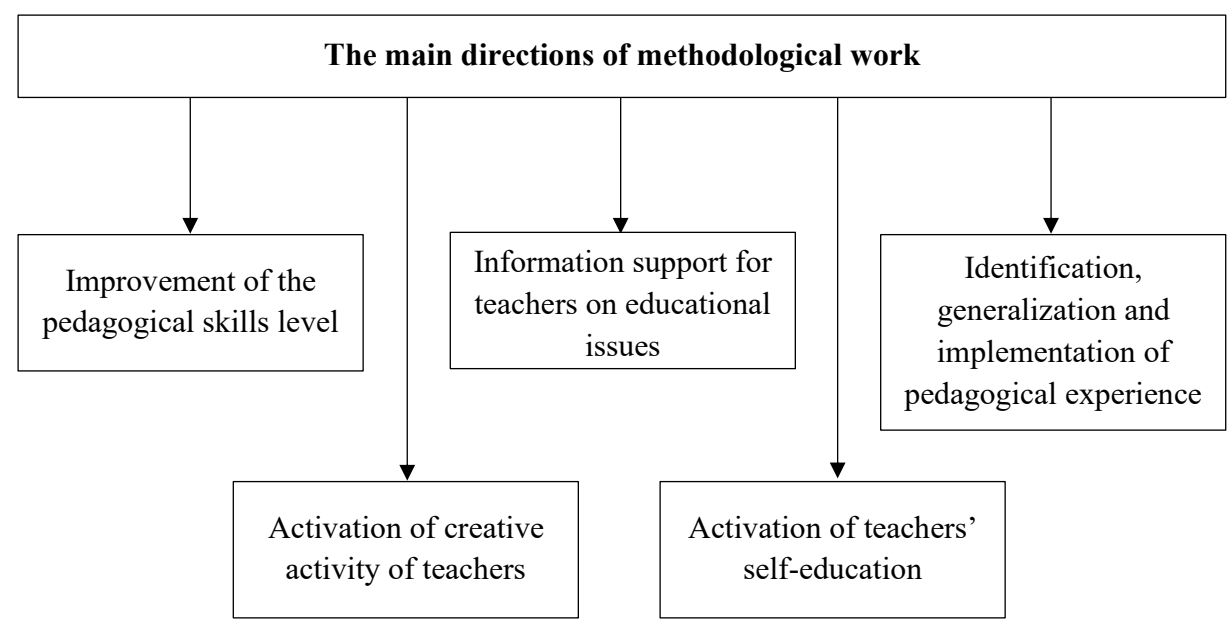

\section{Scheme 1.1. The main directions of methodological work}

The leading technology of methodological work that most meets modern requirements is methodological support - a set of various forms of partnership interaction between educational entities, measures that provide assistance to specialists in overcoming difficulties throughout their professional activities. In modern psychological and pedagogical research, there is no single definition and interpretation of the concept of «methodological support» (Oliinik, 2009: 20-22).

Modern researchers note that in contrast to traditional forms of training, methodological support of the teacher's activity has the following advantages: individualization and flexibility; has a greater potential of an instrumental nature; to a greater extent takes into account the dynamics of development of both the teacher himself, the institution in which he works, and the system of permanent interaction in general; more multidimensional, as it provides constant interaction of the teacher with other subjects of training (Muromets, 2012: 325).

On the vector and targeted orientation of methodological support, modeled on the principles of a competence-based approach (social, professional and personal), depending on individual requests, needs, motivations of each individual teacher or teaching staff, its professional capabilities, notes S. Makarenko. Among the types of support in terms of content are distinguished diagnostic, informational, educational, methodological, scientific, as well as consulting, expert, organizational, network and service support. Since these types of support are integrated in content in the system of methodological work, all of them are considered as scientific and methodological support (Makarenko, 2018).

The defining foundations of scientific and methodological support, according to T. Sorochan, are:

- democratic - the ability to take into account different approaches, points of view, collegiality in making a certain decision;

- situation of choice - creation of several variants of programs, models of activity, technologies that provide prerequisites for conscious choice; 
- self-realization - disclosure of the personal potential of each participant in the pedagogical process;

- co-creation - joint activity of subjects who strive to achieve new quantitative and qualitative results (Sorochan, 2005: 77).

Scientific and methodological support as: Subject-subject professional interaction against the background of mastering and implementing innovative methods and technologies in the educational process is defined by T. Sorochan (Sorochan, 2012: 35).

The approaches to the concept of scientific and methodological support indicated by scientists (S. Makarenko, V. Muromets, V. Oliinyk, I. Romanyuk, T. Sorochan, I. Tereshchenko, etc.) determine the renewal of its principles and functions in the context of methodological work (Scheme 1.2):

\begin{tabular}{|c|c|}
\hline $\begin{array}{c}\text { Principles of the methodological } \\
\text { support of teachers }\end{array}$ & $\begin{array}{c}\text { Functions of the methodological } \\
\text { support of teachers }\end{array}$ \\
\hline diagnostics & advisory \\
\hline democratic & educational \\
\hline systematicity & expert \\
\hline continuity & corrective \\
\hline sequence & moderation \\
\hline succession & adaptive \\
\hline concreteness & informative \\
\hline efficiency & research \\
\hline flexibility & prognostic \\
\hline
\end{tabular}

\section{Scheme 1.2. Basic principles and functions of the methodological support}

Despite the variety of functions, scientific and methodological support is an integral system of interdependent actions and activities aimed at the professional growth of each subject of educational activity; the process of interaction in the teaching staff during the (internal) organization of methodological work in the institution.

The concept of «methodological support» provides pedagogical and psychological assistance and support that provides not the solution of the problem for the teacher, but the organization and stimulation of his amateur activities and the creation of conditions for solving his own problems. One of these conditions is the creation of an educational information space of the institution. A significant role in the implementation of this task is played by scientific periodicals, primarily professional pedagogical publications.

Scientists A. Bondarchuk, N. Didenko, M. Kyrychenko, A. Oliinyk, T. Sorochan and others define the content of methodological support as a complex of interrelated, organized, purposeful actions aimed at helping the teacher solve complications that may occur during educational work. At the same time, it is important that participants of methodological support should become equal partners of this interaction, although they may have different levels of scientific training or mastering practical experience (Oliinik, 2009: 20-22). 
Based on the study of psychological and pedagogical research authored by L. Aleksieienko-Lemovska, I. Dubrovina, I. Zhernosek, I. Kondratets, K. Krutii, I. Romanyuk, I. Tereshchenko, etc.), we have identified the use of various forms of work with teachers in the context of methodological support. Scientific and methodological support involves the use of various interactive methods of working with teachers: business game, training, quest, workshop, casemethod, debates, discussions, etc. (Dubrovina, 2018: 9).

Noteworthy are the results of V. Muromets' research, in which the author identified the stages of using methodological support (Scheme 1.3):

\begin{tabular}{|c|c|}
\hline Stages & The main content \\
\hline Search & $\begin{array}{l}\text { Collecting, summarizing and clarifying information. } \\
\text { Search for possible solutions of the problem. }\end{array}$ \\
\hline Modeling & $\begin{array}{l}\text { Systematization of accumulated information. } \\
\text { Monitoring of results (monitoring). } \\
\text { Defining the purpose, objectives, content, form and methods of work. }\end{array}$ \\
\hline Designing & $\begin{array}{l}\text { Drawing up a plan for joint activities of all subjects } \\
\text { of the pedagogical process. } \\
\text { Organization of problem-related forms of work. }\end{array}$ \\
\hline Support & $\begin{array}{l}\text { Practical implementation of acquired ideas and their elements. } \\
\text { Implementation of a previously planned sequence of actions. }\end{array}$ \\
\hline Reflections & $\begin{array}{l}\text { Comparing the results with the goal set. } \\
\text { Analysis of the degree of implementation of ideas, conclusions. }\end{array}$ \\
\hline
\end{tabular}

Scheme 1.3. Stages of using methodological support (Muromets, 2012)

Using this technology, it is possible to provide scientific and methodological support for the activities of teachers in various areas of educational work, since the activity of providing methodological support here is algorithmized, clear, and transparent.

Thus, the analysis of the results of scientific and pedagogical research allowed us to find out that methodological support is considered as a complex of various forms of methodological work, which is a specially organized, planned activity. In the process of methodological support, favorable conditions are created for the scientific and methodological formation and growth of all participants of the educational process. The main purpose of methodological support is to implement professional and pedagogical self-realization of each member of the teaching staff. The result of methodological support is a qualitatively new activity of teachers, which is manifested in their professional competence and, most importantly, in improving the quality of educational work with children and interaction with family members of pupils.

Since another issue of the study is the professional development of teachers of preschool education institutions, at the fourth stage we turned to its study. It should be noted that this issue is very relevant in psychological and pedagogical research of recent years, as evidenced by the presence of theoretical works and individual publications. Thus, the aspects of professional development of a specialist are reflected in the works of E. Zeier, E. Klymov, T. Kudryavtsev, 
A. Markova, V. Shadrykov and others. Based on the analysis of the main provisions of the theoretical works of these researchers, we came to the conclusion that in the modern psychological and pedagogical literature there is no single approach to substantiating the essence of the concept of «professional development». This analysis allowed us to reveal that the term we are analyzing is considered by modern scientists as:

- the process of professionalization of the individual, the result of which is the achievement of social maturity, the development of new professionally important qualities of the individual, the transition to the next level of professionalism (Markova, 1996: 308);

- the level of performance of a person's professional activity (Kudryavtsev, 1986: 105);

- the degree of professional maturity (Super, 1957);

- social situation of development and leading activity (Zeier, 2013: 416).

In psychological and pedagogical research, there is an ambiguity in the understanding of the concept of «professional development» by representatives of various scientific approaches. In the works of G. Ball, E. Zeier, E. Klimov and other representatives of the activity approach, professional formation is considered as the process of entering a person into a profession, the psychological passage of certain stages of professional development, the main indicators of which are the formation of professional experience and professionally important qualities (Klimov, 1996: 512). From the standpoint of a system-structural approach, the professional development of a person is considered through the interrelation and integrity of professional abilities and professionally important qualities that determine the success of activity (Povarenkov, 2002: 160). Representatives of the value-motivational approach (O. Borysova, I. Sapogova, N. Selezneva, V. Serzhantov, V. Shadrikov, etc.) consider the development of professional motivation based on the formation of value orientations to be the main aspect of professional formation (Selezneva and others, 2007: 80-88).

According to L. Mitina, the effectiveness of professional development of a future teacher is determined by objective indicators that allow assessing the degree of individual compliance with the requirements of the profession, and subjective indicators that reveal the degree of compliance of professional activity with the requirements of the individual (Mitina, 1990: 58-64).

It is valuable that a number of researchers (M. Bityanova, I. Verbytska, S. Kyrdyankyna, etc.) consider the issue of methodological support as a means and technology of professional development of a specialist. In particular, M. Bityanova considers support as a system of professional activity of the pedagogical community, aimed at creating socio-psychological conditions for successful training and psychological development of the future specialist in interaction situations. In addition, according to M. Bityanova's definition, «Support refers to a philosophy of work that creates a combination of the goals of pedagogical practice and focuses on the main thing - on the personality of children» (Bityanova, 1995: 64).

According to the research of S. Kyrdyankyna, methodological support of professional development of a specialist is «a scientifically based way of interaction of the accompanying (mentor, experienced specialist) and the accompanied (teacher), aimed at continuous self-development in the profession, due to quantitative and qualitative, meaningful and structural transformations of the individual, which will lead to natural improvement, to gradual growth in the profession» (Kyrdyankyna, 2011: 27).

In our opinion, I. Verbytska's research deserves special attention. Based on taking into account the requirements and social expectations of a modern educator, I. Verbytska formulated the following directions for implementing methodological support for the professional development of a teacher:

- improving the professional competence of all participants of the educational process; 
- providing the necessary analytical and informational materials;

- pedagogical designing;

- monitoring and evaluation (diagnostics);

- providing the necessary assistance to participants of the educational process (in accordance with their individual needs);

- ensuring the quality and availability of internet services;

- creation of creative centers, in order to improve the professional skills of teachers;

- use of interactive forms of improving skills in the professional activity of a teacher (Verbytska, 2018: 467-469).

Based on the analysis of scientific sources, it is possible to substantiate the judgment that the process of methodological support for the professional development of preschool teachers should have internal (personal) and external (environmental) components. The internal component is to ensure the personal development of a preschool education specialist by forming (providing) a number of stimulating factors. The most important among them is the development of motivation for professional development and improvement, as a set of motivating factors that determine the activity of the individual (Podkorytova, 2018: 96-99).

Both at the stage of professional education, and in the period of further professional development of a preschool teacher the most important condition is to improve its professional competence. This factor applies both to the internal component (professional self-improvement) and to the external one (advanced training courses, pedagogical mentoring, etc.

An important component of the internal component of professional development is the teacher's acquisition of ways to effectively overcome the causes and, most importantly, the consequences of professional stress, which involves teachers mastering the technologies of reflection and self-reflection.

The external component of methodological support for the process of professional development of a preschool teacher provides the implementation of all possible areas of methodological assistance, according to the regulatory documents regulating this issue. The most important of them, in our opinion, are ensuring a holistic pedagogical environment, focusing on professional development and adaptation of young teachers, improving their professional competence and forming the motivation of specialists for effective innovative pedagogical activities (Sitnik, 2015: 41-47).

\section{Conclusion}

The analysis of theoretical sources gives grounds to assert that the modern view of professional development implies its understanding as a productive development of the individual in the process of mastering his professional activity. Successful professional development of a preschool teacher is possible, in our opinion, by providing appropriate methodological support.

Based on the analysis of the achievements of modern psychological and pedagogical thought, as well as regulatory documents, we came to the conclusion that methodological support for the professional development of preschool education teachers should be implemented by organizing activities taking into account the internal and external components, the content and structure of which is described in this study.

Summarizing the above, we conclude that this approach will optimize the process of professional adaptation of young teachers, increase the level of their professional competence and, most importantly, the quality of educational work with preschool children and cooperation with the families of pupils. 


\section{References}

Akademichnyi tlumachnyi slovnyk ukrainskoi movy (1979). [Academic explanatory dictionary of the Ukrainian language] v 11 tomakh (1970-1980). Tom 10. URL: http://sum.in.ua/ (data zvernennia 26. 07.2021). [in Ukrainian].

Bitianova, N. R. (1995) Psihologiya lichnostnogo rosta [Psychology of personal growth]. Moskva [Moscow]. Mezhdunarodnaya pedagogicheskaya akademiya. [in Russian].

Derzhavna natsionalna prohrama "Osvita» ("Ukraina XXI stolittia») (1993). [State National Program «Education» ("Ukraine of the XXI Century»)]. Postanova Kabinetu Ministriv Ukrainy. URL: https://zakon.rada.gov.ua/laws/show/896-93-\%D0\%BF\#Text (data zvernennia 26. 07. 2021) [in Ukrainian].

Diatlenko, N. M. (2009). Pedahohichni idei B. D. Hrinchenka v konteksti onovlennia suchasnoi doshkilnoi osvity [Pedagogical ideas of BD Grinchenko in the context of renewal of modern preschool education]. "Mrii, vystrazhdani zhyttiam...» Do 145-yi richnytsi z dnia narodzhennia B.D. Hrinchenka: kol. monohrafiia (u dvokh chast.): Ch. 1 / V.O. Ohneviuk, N.M. Hupan, N.P. Dichek [ta in.]. Kyiv [Kiev]. KMPU imeni B. D. Hrinchenka. [in Ukrainian].

Dubrovina, I. V., Melnichenko, A. V. (2018). Orhanizatsiia metodychnoi roboty v osvitnikh ustanovakh z rozvytku tvorchoho potentsialu pedahohiv-vykhovateliv [Organization of methodical work in educational institutions for the development of creative potential of teachers-educators]. Naukovyi chasopys NPU imeni M. P. Drahomanova. Seriia 16 : Tvorcha osobystist uchytelia: problemy teorii i praktyky. [in Ukrainian].

Entsyklopediia osvity (2008). [Encyclopedia of Education]. Akad. ped. nauk Ukrainy. Holov. red. V.H. Kremen. Kyiv [Kiev]. Yurinkom. Inter. [in Ukrainian].

Kirdyankina, S. V. (2011). Nauchno-metodicheskoe soprovozhdenie professionalnogo rosta uchitelya [Scientific and methodological support for the professional growth of teachers]. Avtoreferat dis. kand. ped. nauk. 13.00.08. Teoriya $i$ metodika professionalnogo obrazovaniya. Dalnevostochnyj gosudarstvennyj gumanitarnyj universitet. Habarovsk [Khabarovsk]. [in Russian].

Klimov, E. A. (1996). Psihologiya professionalnogo samooprededeleniya [Psychology of professional self-determination]. Rostov-na-Donu [Rostov-on-Don]. Feniks. [in Russian].

Kornieieva, O. L. (2012). Orhanizatsiia metodychnoi roboty z vykhovateliamy doshkilnykh navchalnykh zakladiv [Organization of methodical work with educators of preschool educational institutions]. Avtoref. dys. kand. ped. nauk 13.00.08 DZ Pivdennoukr. nats. ped. un-t im. K. D. Ushynskoho. Odesa [Odessa]. [in Ukrainian].

Krutii, K. L. (2004). Hrupovi formy metodychnoi roboty z pedahohamy v suchasnomu doshkilnomu navchalnomu zakladi [Group forms of methodical work with teachers in a modern preschool educational institution]. Za zah. red. K. L. Krutii. Zaporizhzhia [Zaporizhzhia]. TOV LIPS LTD. [in Ukrainian].

Kudryavcev, T. V. (1986). Psihologiya professionalnogo obucheniya i vospitaniya [Psychology of vocational training and education]. Moskva [Moscow]. MEI. [in Russian].

Makarenko, S. (2018). Naukovo-metodychnyi suprovid yak providna tekhnolohiia metodychnoi roboty na shliakhu do novoi ukrainskoi shkoly [Scientific and methodological support as a leading technology of methodical work on the way to a new Ukrainian school]. International Journal of Innovative Technologies in Social Science. URL: http://archive.ws-conference.com/ wp-content/ uploads/ijitss0143.pdf (data zvernennia: 23. 07. 2021) (in Poland).

Maksymenko, V. P. (2013). Dydaktyka: kurs lektsii [Didactics: a course of lectures]. Navch. Posibn. Khmelnytskyi [Khmelnytskyi]. Khm TsNP. [in Ukrainian]. 
Markova, A. K. (1996). Psihologiya professionalizma [Psychology of professionalism]. Moskva [Moscow]. Mezhdunarodnyj gumanitarnij fond Znanie. [in Russian].

Mishchenko, S. H. (2016). Metodychnyi suprovid profesiinoho zrostannia vykladacha [Methodical support of professional growth of the teacher]. Visnyk Dnipropetrovskoho universytetu imeni Alfreda Nobelia. Pedahohika i psykholohiia. Dnipro [Dnipro]. [in Ukrainian].

Mitina, L. M. (1990). Formirovanie professionalnogo samosoznaniya uchitelya [Formation of the teacher's professional self-awareness]. Moskva [Moscow]. Voprosy psihologii. [in Russian].

Muromets, V. H. (2008). Naukovo-metodychnyi suprovid formuvannia preventyvnoho vykhovnoho seredovyshcha zahalno-osvitnoho navchalnoho zakladu. [Scientific and methodological support for the formation of a preventive educational environment of a general educational institution]. Teoretyko-metodychni problemy vykhovannia ditei ta uchnivskoi molodi. Zb. nauk. pr. Kam. -Pod. nats. univ. im. I. Ohiienka, Kam. -Pod. [Kamianets-Podilskyi]. [in Ukrainian].

Nochvolod, L. I. (2008). Suchasnyi slovnyk inshomovnykh sliv [Modern dictionary of foreign words]. Kharkiv [Kharkiv]. Torsinh plius. [in Ukrainian].

Oliinyk, V. V. (2009). Modernizatsiia systemy pisliadyplomnoi pedahohichnoi osvity Ukrainy $v$ umovakh zmin [Modernization of the system of postgraduate pedagogical education of Ukraine in the conditions of changes]. Pisliadyplomna pedahohichna osvita: yevropeiski oriientyry ta rehionalni priorytety. Tezy mizhnar. nauk.-prakt. konf. Bila Tserkva, [White Church]. [in Ukrainian].

Pidkorytova, H. I. (2018). Upravlinnia protsesom profesiinoho stanovlennia molodykh pedahohiv [Management of the process of professional development of young teachers]. Molodyi vchenyi. [in Russian].

Povarenkov, Yu. P. (2002). Psihologicheskoe soderzhanie professionalnogo stanovleniya cheloveka [The psychological content of a person's professional development]. Moskva [Moscow]. URAO. [in Russian].

Prymirne polozhennia pro metodychnyi kabinet zakladu doshkilnoi osvity (2018). [The approximate regulations on the methodological office of a preschool education institution]. Nakaz MON Ukrainy. URL: http://ru.osvita.ua/legislation/doshkilna-osvita/60597/(data zvernennia 20. 07. 2021 p.) [in Ukrainian].

Romaniuk, I. A. (2019). Plan roboty zakladu doshkilnoi osvity: pryntsypy, struktura, zmist. Krok za krokom do realnoho planu efektyvnykh dii [The work plan of the preschool institution: principles, structure, content. Step by step to a real plan of effective action]. Metod, posib. Ternopil [Ternopil]. Mandrivets. [in Ukrainian].

Selezneva, N. T., Ivanova, N. G. (2007). Izuchenye protsessa lychnostno-professyonalnoho stanovlenyia budushchykh psykholohov [The study of the process of personal and professional formation of future psychologists]. Moskva [Moscow]. Psihologiya obrazovaniya. [in Russian].

Sitnik, A. P. (2015). Molodoy uchitel nuzhdaetsya v pomoschi [The young teacher needs help]. Moskva [Moscow]. ANO ID Narodnoe obrazovanie. [in Russian].

Slovar-spravochnik po pedagogike (2004). [Dictionary-reference on pedagogy]. Avt-sost. V. A. Mizherikov. Moskva [Moscow]. TC Sfera. [in Russian].

Slovnyk bazovykh poniat z kursu Pedahohika (2014). [Dictionary of basic concepts from the course «Pedagogy»]. Navchalnyi posibnyk dlia studentiv vyshchykh navchalnykh zakladiv. Ukladach O.I. Antonova. Zhytomyr [Zhytomyr]. Vyd-vo ZhDU imeni Ivana Franka. [in Ukrainian]. Sorochan, T. (2012). Spivtvorchist - odna z oznak tekhnolohii naukovo-metodychnoho suprovodu [Co-creation is one of the features of the technology of scientific and methodological 
support]. Mater. naukovo-praktychnoi konf. Aktyvizatsiia tvorchoho potentsialu uchnivskoi molodi v konteksti hlobalizatsii osvity. [in Ukrainian].

Sorochan, T. M. (2005). Bezperervnyi protses rozvytku profesionalizmu pedahohiv u systemi pisliadyplomnoi osvity [Continuous process of development of professionalism of teachers in the system of postgraduate education]. Kyiv [Kiev]. Pisliadyplomna osvita v Ukraini. [in Ukrainian].

Super D.E. (1957). et al. Vocational Development: A Framework of Research. New York. [in USA].

Velykyi tlumachnyi slovnyk suchasnoi ukrainskoi movy (2005). [Large explanatory dictionary of the modern Ukrainian language]. $250000 \mathrm{sl}$. Ukl. ta hol. red. V.T. Busel. Kyiv-Irpin [KievIrpen]. Perun. [in Ukrainian].

Verbitskaya, I. B. (2018). Metodicheskoe soprovozhdenie pedagogov doshkolnyih obrazovatelnyih uchrezhdeniy [Methodological support of teachers of preschool educational institutions]. Molodoy uchenyiy. URL: https://moluch.ru/archive/207/50749/(data zvernennia 27. 07. 2021). [in Russian].

Zakon Ukrainy «Pro doshkilnu osvitu» (2001). [Law of Ukraine «On Preschool Education»]. URL: https://zakon.rada.gov.ua/laws/show/2628-14\#Text (data zvernennia: 20.07.2021). [in Ukrainian].

Zakon Ukrainy «Pro osvitu» (2017). [Of the Law of Ukraine «On Education»]. URL: https:// zakon.rada.gov.ua/laws/show/2628-14\#Text (data zvernennia: 20. 07. 2021). [in Ukrainian].

Zeier, E. F. (2013). Psihologiya professionalnogo obrazovaniya [Psychology of vocational education]. Uchebnik dlya studentov uchrezhdenij vysshego professionalnogo obrazovaniya. Moskva [Moscow]. Izdatelskij centr Akademiya. [in Russian].

Zhernosiek, I. P. (2001). Udoskonalennia naukovo-metodychnoi roboty $v$ suchasnykh zahalnoosvitnikh shkolakh, litseiakh i himnaziiakh [Improving scientific and methodological work in modern secondary schools, lyceums and gymnasiums]. Kyiv [Kiev]. Vipol. [in Ukrainian]. 